\title{
Corporate Social Responsibility and Corporate Social Innovation: A Conceptual Understanding
}

\author{
Muhamad Nizam Jali ${ }^{1, *}$, Zakaria $\mathrm{Abas}^{2}$, and Ahmad Shabuddin Ariffin ${ }^{3}$ \\ ${ }^{1}$ UUM, College Of Business, 06010 Sintok Kedah, Malaysia \\ ${ }^{2}$ UUM, College Of Business, 06010 Sintok Kedah, Malaysia \\ ${ }^{3}$ UUM, College Of Business, 06010 Sintok Kedah, Malaysia
}

\begin{abstract}
In decades, various organizations worldwide engaged with Corporate Social Responsibility (CSR) in order to show their corporate commitments and responsibilities towards societies at large. These commitments and responsibilities are coming from monetary and nonmonetary resources for example cash, equipment's and human resources whom are used for social purposes and activities that leads to a betterment of society and also to improved organization reputation. However, in today's knowledge and innovation led economy, organizations can no longer affords to get involve in charity and community services merely to fulfil social return without having any sort of economic payoffs. This situation warrants organizations moving beyond CSR to Corporate Social Innovation. This paper explores conceptual understanding between CSR and Corporate Social Innovation. CSR is a traditional philanthropy and old paradigm which is somewhat no longer sufficient in coping with current economic situation. Hence, this paper provides an insight and suggests that corporate social innovation as an emergence new paradigm that perhaps could provide a comprehensive representation in the era of knowledge and innovation led economy that will leads to real change in improving the well-being of people's life, enhance economic and technological growth. Furthermore, this paper also highlighted knowledge resource is the most significant resource of Corporate Social Innovation.
\end{abstract}

Keywords: CSR, Corporate Social Innovation, Knowledge resource

\section{Introduction}

For more than five decades, organizations and business entities include CSR in their strategic planning and operational decision making process. By incorporating CSR activities for example philanthropy and volunteering in their main business plan structure, organizations are said fulfilling its obligation towards the welfare of its society. According to [1], sustainability of business growth does not entirely dependent upon its economic performance but most importantly how business deals and interacts with society around

*Corresponding author: mnj_jali@yahoo.com.my 
them, which in turn contributes massively towards society and environment betterment. However, present turbulence of business environment, intense competition pressure, globalization and technological change offers organization no other choice but an absolute ultimatum in order to stay survival, to keep abreast with competitive demands and technological change and to ensure long-term business prosperity [2, 3]. From the above challenging and competitive economic situation, [4] stressed that organization and business entities can no longer affords to engage in CSR activities solely to fulfil social responsibilities without reap a commercial return on their contributions on CSR [4]. Organization and business entities must move beyond the traditional nature of CSR to a new paradigm that can cope with the demands and needs of present dynamic economic environment. According to [5], this new paradigm offers organization and business entities a massive return towards both social as well as commercial benefits.

From the above paragraph, corporate social innovation has emerged as the new emerging paradigm of innovation and received an overwhelming interest from organization and business entities worldwide in order to gained commercial driven benefits and at the same time contributes towards the development of human well-being and societal quality and quantity of life $[6,7,8]$. As a result, many multinational organization worldwide among others IBM, Napp Pharmaceuticals, GlaxoSmithKline, Novartis, Siemens, Microsoft, McDonald restaurant and Nike emphasis and focus more on corporate social innovation as compared to CSR in their main business outcome strategy initiatives [9, 10, 11, 12]. For example, GlaxoSmithKline, Novartis and Napp pharmaceutical creating inimitable pharmaceutical products, processes and services in specific diseases area by embedding new knowledge resource through partnership with university and consequently improves wider society quality of life and gained a substantial amount of commercial benefits in return [11]. In addition, IBM and Microsoft through knowledge resource collaboration also with university partners in the various engineering fields for example in computer and mechanical engineering creating new innovation on their products, processes and services which in turn offers society to enjoy a high-end computer and electronic products and at the same times gaining a huge amount of market share as compared to their competitors [13]. Moreover, [5] highlighted organization and business entities must viewed knowledge partnership and social sector activities as the source of opportunities to developed new ideas and innovation, enhance market needs and solving long-standing business problems and leaving behind old perception that viewed social sector activities just as a dumping ground for spare resources i.e. cash, equipment and human resource [14].

On the other hands, present economic environment is moving into knowledge based society where new knowledge resource is regard as the most valuable intangible resource that can be embedded into products, processes and services in order to fulfil private and social needs $[15,16]$. With that, the association of corporate social innovation and knowledge resource is immensely important considering its contribution towards social and economic aspects. Thus, a complete and extensive understanding on the insight between CSR and corporate social innovation must be well understood. This is the primary purpose of this paper. This paper is set out in three sections. First, the paper examines the existing CSR literature. Secondly, this paper reviews the literature of social innovation within the context of knowledge and innovation led economy. This paper will also discuss on the knowledge resource as an essential resource for corporate social innovation. Thirdly, the paper ends by enveloping the conclusion of the thought. 


\section{Review of CSR}

The general concept and definition of CSR is describes as the social responsibilities and obligation that organization and business entities have to the societies and environment within which their businesses operate. Specifically, literature highlighted that the classic notion of CSR is associated with the terms among others, social responsible behaviour, social legal responsibility to the citizens and also a charitable contribution to the society and environment [17]. According to [18], CSR encompasses a wide range of voluntarily works that contributes to the better society and cleaner environments. From the above statements, [19] established a formal and organised definition and deepens the understanding on CSR. The authors defined CSR as how organization and business entities socially interacts with employees, suppliers, customers and communities as a whole by integrating monetary and non-monetary resources in a continuous way that can leads to a better society and cleaner environments [20]. Within the literature, CSR have various definition and interpretation, but the common ground of understanding is that CSR is refers to an organization and business entities that made a continuous commitment and obligation through financial and non-financial assets towards social activities and program without having any inclination with their day-to-day business operations i.e. commercial driven benefits, but merely to show legal social responsibility and social connection to the community.

Within the literature of CSR, huge amount of empirical studies shows evidence to support and sums-up the above paragraph, whereby most organizations engaging with CSR only to fulfils non-commercial driven outcomes. Studies by [21, 22] examines the impacts of CSR activities towards organization reputation. Based on their findings, it shows that various multinational organization for example BP, Shell and tobacco related organization engaged with CSR activities i.e. charity, volunteer, philanthropy, only for the purpose of enhancing their organization reputation. For these organizations, CSR successfully creates a favourable corporate image and positive relationship on improving organization image in the eyes of the society at all level [23]. A study by [24] acknowledge that by getting a good corporate reputation through engagement in CSR activities does not necessarily shows organization is having a good financial performance. Furthermore, studies by [25, 26, 27] on CSR activities and environmental sustainability also explained the above notion. In their studies, they highlighted the main reason of multinational organization engaged and allocated substantial amount of resources on CSR activities are only due to satisfy and absorb social and political pressures on the issues of environmental sustainability. To elaborate further, their studies explained that oil and gas companies, mining companies and other related environmental issue companies address the issues of environmental sustainability simply by mobilizing spare resources towards environmental charity program and participating in an environmental corporate volunteer program. By doing this, they at least show their sense of caring towards improving and to ensure continuous environmental sustainability with regards to the nature of the business that they are dealing with. Even though such CSR activities should be encourage, but the activities have not produce any sort of return on the part of business point of view [5].

The literature also gives evidence that CSR have positive relationship with customer loyalty and satisfaction [28]. Various empirical studies among others by [29, 30, 31] found that when organization and business entities continuously engaging with CSR activities, it have a significant positive relationship with customer loyalty and satisfaction in regards to the brands and image of the organization. In contrast, [32] argued that even though CSR activities helps firms to secured loyal customers and enhance customers satisfaction, 
however, this situation does not gives a significant effects on the firm financial performance. Therefore, considering present competitive economic demands, CSR is somehow viewed as insufficient for organization and business entities to continue with. Thus, organization and business entities must be able to find a new platform and paradigm in dealing with the present economic demands that can fulfils both social and commercial return that can leads to long-term business prosperity and to stay survival. Figure 1 illustrates the conceptual view of CSR towards social benefits.
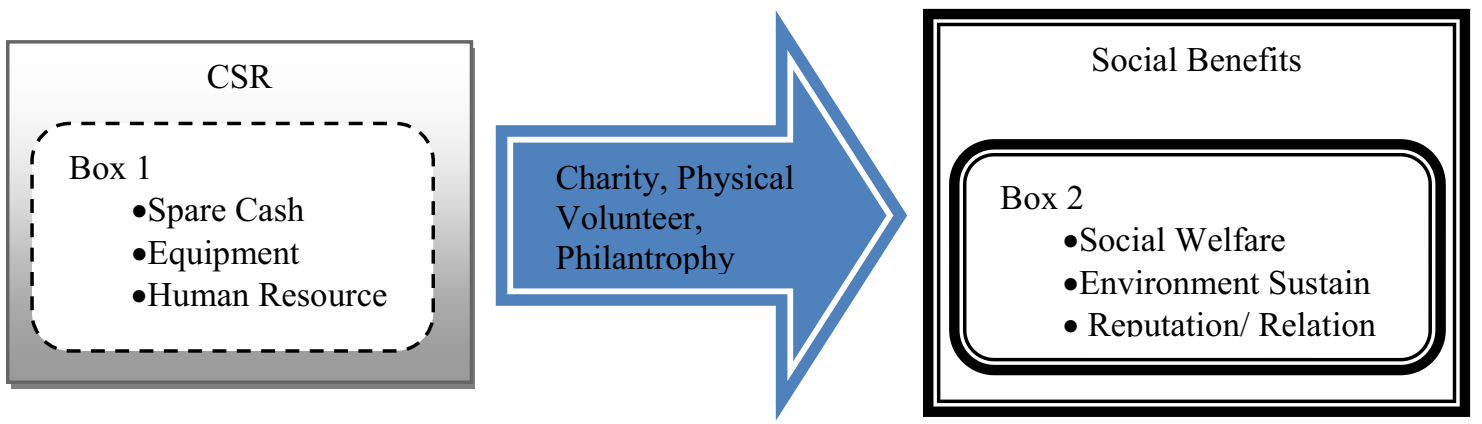

Fig. 1. Conceptual view of CSR towards social benefits.

Figure 1 provides summary of the conceptual view of CSR towards social benefits. Box 1 in the CSR indicates the resources i.e. spare cash, equipment, human resource; Box 2 signifies the contribution of CSR through charity, physical volunteer activities and philanthropy towards social benefits i.e. social welfare, environmental sustainability and good interaction and relation. The next section explained the new paradigm i.e. corporate social innovation, which is more sufficiently comprehensive as compared to CSR within the era of knowledge and innovation led economy.

\section{Review of Corporate Social Innovation}

In the literature, corporate social innovation can be defined as new and novel solution embedded into products, processes and services in order to fulfil social needs and to improved quality and quantity of life [33, 15]. Specifically, corporate social innovation includes and integrates social, economic and technological approach in order to meet the demands and pressures of new economic environment $[34,35]$. With the integration of social, economic and technological approach, there is a collective dynamic interplay that guarantees organization and business entities a considerable return with regards to these three aspects [36, 15]. As a result, corporate social innovation is seen as the new and outstanding emerging paradigm in order to resolve social, economic and technological issues face by all related parties and attracting the interest and attention of private sectors, policy makers and researches worldwide [6,37]. According to [38], unlike CSR, corporate social innovation is not necessarily tied up to address specific social purposes but its significant value encompasses wide range of contribution outcomes that includes social, economic and technological benefits. To elaborate further, when organization and business entities implements corporate social innovation in its strategic planning and operational decision making process, it address social and economic issues among others, poor social health, poor education, social income inequality, massive unemployment and poor economic growth [39], this in turn leads to the outcome of profit maximization of private sectors, enhance economic growth, improves living condition of society, better 
environmental condition and developed and enhance individual's knowledge, skills and competencies [40].

From the above paragraphs, various empirical studies give evidence to justify the outcomes of corporate social innovation. According to [5], corporate social innovation helps to improves societal and economic problems by creating new solution, which refers to knowledge resource embedded into products, processes and services that work to meet pressing social and economic needs and to improve quantity and quality of people's life. Studies by $[5,41]$ stressed that in the aspects of poor public education, corporate social innovation offers new solutions that comes from knowledge resource that contributes to a better future knowledge workers and at the same time helps specific private sectors gained a substantial amount of market share between competitors. Furthermore, according to [42], the result of deployment of corporate social innovation and knowledge resource on the issues of massive unemployment contributes towards increase in employment among people and also increase in consumption of economic benefits. According to [43, 22], corporate social innovation and knowledge resource leads to the introduction of superior products, processes and services that have a multiplier effects on the economic value in terms of profit maximization, market share monopoly and increase in private performance. A study by [44] also revealed on the positive effects of corporate social innovation and knowledge resource on the issues of social health. Their study found that knowledge resource leads to the establishment of superior medical products that can improves and enhance people's health and subsequently gives a significant return towards profit maximization to the parties involved. Apart from that, $[45,16,46]$ describe the new and novel solution which is the main element of corporate social innovation refers to the superior knowledge resource. This superior knowledge resource is embedded into products, processes and services which make them highly innovative and in turn lead to the outcome of improving society well-being that include environmental issues, stimulate economic growth and enhance private needs i.e. profit maximization, market share monopoly and private performance [38]. A recent study by [47] found that a linkage between superior knowledge resource and corporate social innovation is the best possible solution in producing superior products, processes and services towards overcoming social and economic and technological problems. New superior knowledge resource is created through the processes of strategic knowledge management that involves the process of knowledge creation, knowledge transfer and knowledge application [48, 49]. These processes involved the interplay of tacit and explicit knowledge [43, 50]. Figure 2 illustrates the conceptual view of corporate social innovation towards social, economic and technological benefits.
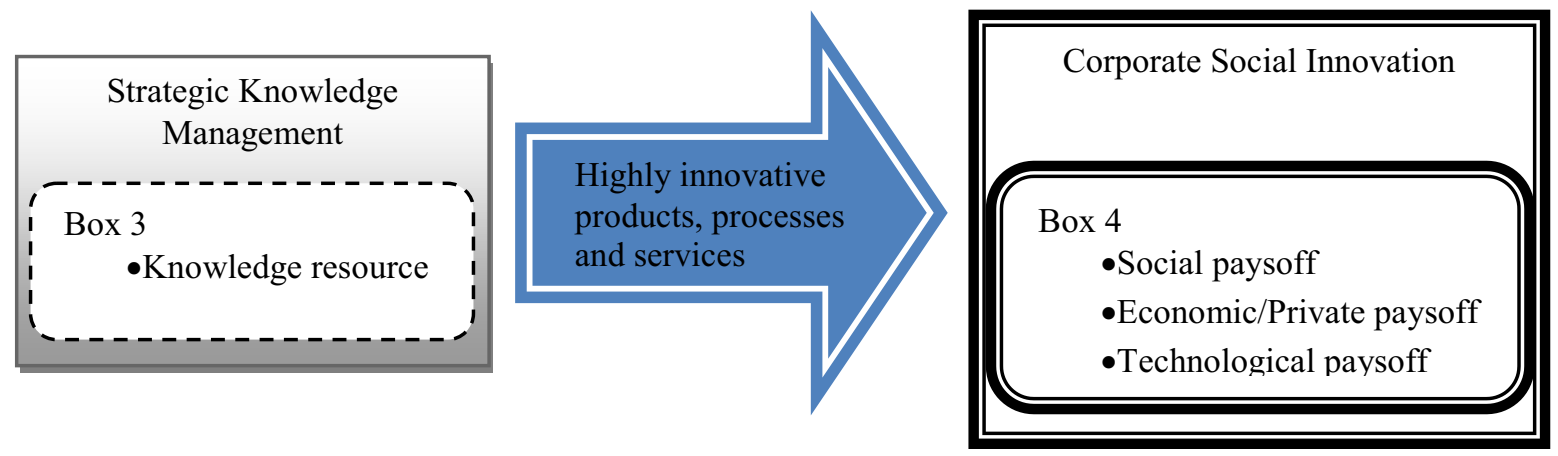

Fig.2. Conceptual view of corporate social innovation towards social, economic and technological benefits 
Figure 2 provides summary of conceptual understanding of corporate social innovation and its association with knowledge resource within strategic knowledge management processes. Box 3 in the strategic knowledge management indicates the output i.e. knowledge resource and box 4 signifies the contribution of knowledge resource on corporate social innovation i.e. social, economic and technological payoffs; by producing highly innovative products, processes and services. Therefore, even though CSR approach is still applicable if not entirely out dated, but Corporate Social Innovation offers all parties concern i.e. private and public institutions, a better opportunity in optimizing social, economic and technological payoffs.

\section{Conclusions}

This paper provides an overview of the existing literature on CSR and corporate social innovation. This paper also provides a brief linkage between knowledge resource and corporate social innovation. The literature highlighted even though CSR can accomplish many social benefits and should be encouraged, but with the demands and pressures of present economic environment, CSR is seen as inadequate and not an ideal solution for organization and business entities to hold on in order to leverage social, economic and technological payoffs concurrently. This paper suggest that corporate social innovation is the new outstanding paradigm that are more sufficient within the era of knowledge and innovation led economy that provide real change in improving the well-being of people's life, enhance economic and environmental growth as well as technological growth. In addition, knowledge resource created through the processes of knowledge creation, knowledge transfer and knowledge application is the vital intangible resource for the success of corporate social innovation. Therefore, there is an urgent need of comprehensive and extensive understanding and analysis on the empirical evidence of corporate social innovation and its relatedness with superior knowledge resource [51]. This new area must be seriously engaged by future research. Thus, this paper hopefully offers an improved understanding and new insight on understanding current states of CSR and new emerging paradigm of corporate social innovation and its linkages with knowledge resource within the context of economic and business environment.

The authors would like to thank the anonymous reviewers. The authors would also like to give special thanks to the Knowledge Transfer Programme (KTP) secretariat for the funding received under the KTP special research programme titled KTP Problem Statements of Industry/ Community Problems in Malaysia and ASEAN Region, SO code 13319.

\section{References}

1. A. Lindgreen, V. Swaen, International Journal of Management Reviews. Corporate social responsibility. 12(1), 1-7 (2010).

2. C. Bartlett, S. Ghoshal, Sloan Management Review. Building competitive advantage through people. 43(2), (2013).

3. R.A. Bettis, M.A. Hitt, Strategic Management Journal. The new competitive landscape. 16(S1), 7-19 (1995).

4. H. Aguinis, A. Glavas, Journal of Management. What we know and don't know about corporate social responsibility a review and research agenda. 38(4), 932-968 (2012). 
5. R.M. Kanter, Harvard Business Review. From spare change to real change: The social sector as beta site for business innovation. Vol. 77 No. 3, pp. 122-132 (2015).

6. E.W. Lee, J.M. Restrepo, Policy \& Politics. Institutional embeddedness and the scaling-up of collaboration and social innovation: the case of a Hong Kong-based international NGO. 43(3), 459-471 (2015).

7. J. Cunha, P. Benneworth, Paper presented at the EURA Conference 2013, Enschede, The Netherlands. Universities contributions to social innovation: towards a theoretical framework. 3-6 July (2013).

8. M. Lizuka, Working paper series United Nations. Maastricht, The Netherlands Innovation. Innovation systems framework: still useful in the new global context?. UNU-MERIT. 005 (2013).

9. A. Cadbury, Twenty-First Century Society. Corporate social responsibility. 1(1), 5-21 (2006).

10. J. Saul, John Wiley \& Sons. Social Innovation, Inc.: 5 strategies for driving business growth through social change (2010).

11. M. Perkmann, A., Neely, K. Walsh, R\&D Management. How should firms evaluate success in university-industry alliances? A performance measurement system. 41(2), 202-216 (2011).

12. W. Spiess-Knafl, C., Mast, S.A. Jansen, Social Business. On the nature of social business model innovation. 5(2), 113-130 (2015).

13. M. Perkmann, A. Salter, MIT Sloan Management Review. How to create productive partnerships with universities. 53(4), 79 (2012).

14. S. Du, V., Swaen, A. Lindgreen, S. Sen, Journal of Business Ethics. The roles of leadership styles in corporate social responsibility. 114(1), 155-169 (2013).

15. N. Altuna, A. M., Contri, C., Dell Era, F., Frattini, P. Maccarrone, European Journal of Innovation Management. Managing social innovation in for-profit organizations: the case of Intesa Sanpaolo. 18(2), 258-280 (2015).

16. R. Chiva, P., Ghauri, J. Alegre, British Journal of Management. Organizational learning, innovation and internationalization: A complex system model. 25(4), 687-705 (2014).

17. E. Garriga, D. Mele, Journal of Business Ethics. Corporate social responsibility theories: Mapping the territory. 53(1-2), 51-71 (2004).

18. R. Welford, The Journal of Corporate Citizenship. Corporate social responsibility in Europe, North America and Asia: 2004 survey results. (17), 33 (2005).

19. A. Dahlsrud, Corporate social responsibility and environmental management. How corporate social responsibility is defined: an analysis of 37 definitions. 15(1), 1-13 (2008).

20. M. Van Marrewijk, Journal of Business Ethics. Concepts and definitions of CSR and corporate sustainability: Between agency and communion. 44(2-3), 95-105 (2003).

21. S. Bear, N., Rahman, C. Post, Journal of Business Ethics. The impact of board diversity and gender composition on corporate social responsibility and firm reputation. 97(2), 207-221 (2010).

22. Y. Yoon, Z., Gurhan-Canli, N. Schwarz, Journal of Consumer Psychology. The effect of corporate social responsibility (CSR) activities on companies with bad reputations. 16(4), 377-390 (2006).

23. L.M. McDonald, S. Rundle-Thiele, International Journal of Bank Marketing. Corporate social responsibility and bank customer satisfaction: a research agenda. 26(3), 170-182 (2008). 
24. K. Walker, B. Dyck, Business and Society Review. The primary importance of corporate social responsibility and ethicality in corporate reputation: an empirical study. 119(1), 147-174 (2014).

25. F.M., Edoho, Corporate Social Responsibility and Environmental Management. Oil transnational corporations: Corporate social responsibility and environmental sustainability. 15(4), 210-222 (2008).

26. K. Babiak, S. Trendafilova, Corporate social responsibility and environmental management. CSR and environmental responsibility: motives and pressures to adopt green management practices. 18(1), 11-24 (2011).

27. M. Orlitzky, D.S., Siegel, D. A. Waldman, Business \& society. Strategic corporate social responsibility and environmental sustainability. 50(1), 6-27 (2011).

28. P. Martinez, I.R. Del Bosque, International Journal of Hospitality Management. CSR and customer loyalty: The roles of trust, customer identification with the company and satisfaction. 35, 89-99 (2013).

29. S. Du, C.B., Bhattacharya, S. Sen, International Journal of Research in Marketing. Reaping relational rewards from corporate social responsibility: The role of competitive positioning. 24(3), 224-241 (2007).

30. S. Pivato, N., Misani, A. Tencati, A European review of Business ethics. The impact of corporate social responsibility on consumer trust: the case of organic food. 17(1), 3-12 (2008).

31. P.A. Vlachos, N.G., Panagopoulos, A.A. Rapp, Journal of Business Ethics. Feeling good by doing good: Employee CSR-induced attributions, job satisfaction, and the role of charismatic leadership. 118(3), 577-588 (2013).

32. E. Pol, S. Ville, The Journal of Socio-Economics. Social innovation: Buzz word or enduring term? 38(6), 878-885 (2009).

33. J.A. Phills, K., Deiglmeier, D.T. Miller, Stanford Social Innovation Review. Rediscovering social innovation. 6(4), 34-43 (2008).

34. V. Ramaswamy, Strategy \& Leadership. Co-creating value through customers' experiences: the Nike case. 36(5), 9-14 (2008).

35. E. Shaw, A. De Bruin, International Small Business Journal. Reconsidering capitalism: the promise of social innovation and social entrepreneurship? 31(7), 737-746 (2013).

36. K. Pue, C., Vandergeest, D. Breznitz, Innovation Policy Lab White Paper. Toward a Theory of Social Innovation. 2016-01 (2015).

37. A. Unceta, J., Castro-Spila, J. Garcia Fronti, The European Journal of Social Science Research. Social innovation indicators. Innovation: 1-13 (2016).

38. P. Dawson, L. Daniel, International Journal of Technology Management Understanding social innovation: a provisional framework. 51(1), 9-21 (2010).

39. P. Harazin, K. Kosi, Social and Management Sciences. Social Challenges: Social Innovation through Social Responsibility. Periodica Polytechnica. 21(1), 27 (2013).

40. S. Surikova, K., Oganisjana, G. Grinberga-Zalite, Proceedings of the International Scientific Conference. The Role of Education in Promoting Social Innovation Processes in the Society. In SOCIETY, INTEGRATION, EDUCATION. Vol. 4, pp. 233-243 (2015).

41. T. Scheuerle, B., Schmitz, W., Spiess-Knafl, R., Schues, S. Richter, International Journal of Social Entrepreneurship and Innovation. Mapping social entrepreneurship in Germany-a quantitative analysis. 3(6), 484-511 (2015).

42. G. Cajaiba-Santana, Technological Forecasting and Social Change. Social innovation: Moving the field forward. A conceptual framework. 82, 42-51 (2014). 
43. S. El Arifeen, A., Christou, L., Reichenbach, F.A., Osman, K., Azad, K.S., Islam, D.H. Peters, The Lancet. Community-based approaches and partnerships: innovations in health-service delivery in Bangladesh. 382(9909), 2012-2026 (2013).

44. M. Makimattila, T., Junell, T. Rantala, European Journal of Innovation Management. Developing collaboration structures for university-industry interaction and innovations. 18(4), 451-470 (2015).

45. S. Battisti, International Journal of Services Technology and Management. Social innovation: the process development of knowledge-intensive companies. 18(3-4), 224-244 (2012).

46. G. Krlev, E., Bund, E., G. Mildenberger, Information Systems Management. Measuring what matters-Indicators of social innovativeness on the national level. 31(3), 200-224 (2014).

47. D. Lavie, Academy of Management Review. The competitive advantage of interconnected firms: An extension of the resource-based view. 31(3), 638-658 (2006).

48. M. Meier, International Journal of Management Reviews. Knowledge management in strategic alliances: A review of empirical evidence. 13(1), 1-23 (2011).

49. K.L. Turner, M.V. Makhija, Academy of Management Review. The role of organizational controls in managing knowledge. 31(1), 197-217 (2006).

50. P. Benneworth, J. Cunha, European Journal of Innovation Management. Universities contributions to social innovation: reflections in theory \& practice. 18(4), 508-527 (2015). 